\title{
地すべりと岩石の力学的性質
}

\section{— 新潟県山中背斜を例として——}

\section{Landslides and mechanical properties of rocks}

-An example of the Yamanaka anticline, Niigata, Japan-

岩松 睴* 服部昌樹** 西田彰一*

Akira Iwamatsu, Masaki HatToRI and Shoichi Nishida

\section{Abstract}

There are several landslide areas along the axial trace of the Yamanaka anticline which is composed of the Miocene to Pleistocene formations. Landslides are well developed in the hinge of the anticline, but not in the limb, even though the strata are of the same horizon. Especially large landslide areas are situated where the anticlinal axis is curved or warped. It suggests that folding has influence on the development of landslides.

Mudstone and sandy mudstone of the Pliocene formations, collected from the hinge and the limb, are deformed and fractured under condition of triaxial compression at the strain rate of $1 \times 10^{-4} / \mathrm{sec}$. Rocks from the hinge have lower strength, smaller Young's modulus and higher ductility than those from the limb. Longitudinal strain under the hydrostatic pressures of $1,000 \mathrm{~kg} / \mathrm{cm}^{2}$ is greater in the rocks from the hinge. Namely the rocks of the hinge can be strained more easily than those of the limb. It also shows that the rocks of the hinge is weaker to deformation and/or failure including landslide formation. It may be attributed to their textures disturbed by the tectonic flow in folding.

There are different kinds of fractures in the different parts of the anticline. Transversal extension fractures or gashes are well developed in the hinge. As weathering is accelerated by ground-water permeation through these fractures, landslides are well developed in the hinge of the anticline.

\section{1.はじめに}

地すべりは，地表伃よびその近傍で起る地殼構成物質 の変質・破壊・斜面移動などからなる一連の現象であ る1。このようにとらえるならば，地すべりの研究，と くに予知・予測にとって, 構造地質学のはたすべき役割 は非常に大きいといわなければならない。しかしなが ら，従来の地すべり報告書には，その冒頭に地質的素因 の一項がも5けられ，主として，岩質や地層面の傾斜の 方向と地すべりとの関係などが，ほんのつけたりに論じ られているにすぎなかった。地質構造との関係について は，地すべり地の空間的分布が，断層やしょら曲と一致 している場合があると述べられている程度で，その理由 そついて，「地すべりの構造規制」といった観点から， 真正面からとりあげたるのはほとんどみられなかった。 一般に，現象を支配している要因は，「物性」と「場」 の 2 つはっきり区別して考える必要があり，地すべり そついても同様である。植村（1974）は，これを「内的 原因」と「外的条件（環境条件）」と呼んでいる1）。前者 の初生的性質は，岩質や構造の諸因子によって決定され るが，これらは，外的条件の変化に応じて，時とともに

$*$ 新潟大学理学部地盤災害研究施設

** 石油資源關発株式会社技術研究所
変化していく。このように後の諸作用によって付加され る因子をここでは「獲得因子」之呼んで和く。後者の 外的条件は, 変質・風化・造構作用などで, 重力や地形 もある意味ではこれに入れてよい。このようにしてみる と，どのような因子をその後獲得したかによって，地す ベりに対する抵抗力に違いがでてくることになる。筆者 らは，この点に着目して，造構環境とその結果としての 岩石の力学的性質を中心研究をすすめた。このような 研究は，一見あまり迂遠と思われるか子知れないが，地 すべりの研究にとって, 本質的に重要な基礎研究である と考㝋る。

\section{2. 山中背斜の地質と地すべり}

（1）地すべり地形

新潟県の新第三紀層分布地域には, 数多くの地すべり 地が存在している。その中には，乙ゅう曲，とく汇背斜 構造と空間的分布が一致するものも多い2)。新潟県刈羽 郡高柳町東方飞位置する山中背斜 ${ }^{3)}$ もとの一例である

(図-1)。図-2 は，航空写真から判読した地すべり地を 記入したものであるが，地すべり地の分布は背斜軸と見 事に一致し，背斜軸が屈曲しているところでは，やはり 平行して曲っている。とりわけ大きな地すべり地は，北 から，八重沢・塩沢・山中・栃ヶ原・桐山である。これ 
らの地すべり地が，傾斜 $20^{\circ}$ 以下の平たんな低地をなし て，軸部に連続して分布するのに対し，両翼には，これ と対照的に, 傾斜 $30^{\circ} \sim 40^{\circ}$ の高い嶺が平行して連なっ ている。また，地すべり地は水量が豊富なため水田とし て利用されることが多く, 地形図上で, 傾斜地水田 (い

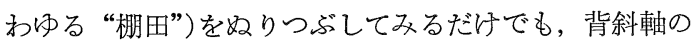
位置を知ることができるほどである（図-3）。このよう に, 同一の地層でも, 翼部には地すべり地があまり見ら れないのに, 軸部には地すべりが発達している。もちろ ん, 同じ場所では, 泥岩のほうが, 砂岩にくらべて地す べりが起きやすく, そのため, 砂岩はケスタ地形やU字 型の山陵（軸部の場合）を形づくっている。

\section{(2) 地質概説}

柏崎市南方の米山火山岩体をとりまいて，比較的短軸 (5 10 km) の背斜が弧状に分布しているが，この山中 背斜もとのひとつである。軸部には後期中新世の椎谷層
が露出し, それを招括って, 順次, 鮮新世の西山層・灰 爪層, 更新世の魚沼層が分布する（図-1）。これらの地 層相互の関係は，いずれも整合である。

椎谷層下部は, 暗灰色ない乙黒色の塊状泥岩（粘土 岩), または暗灰色泥岩之兏白色㠜灰質細〜粗粒砂岩の 互層である。互層は, やや泥質部分のほうが多く, 各単 層の厚さは $10 \mathrm{~cm} \sim 1 \mathrm{~m}$ である。砂岩の多くは級化層理 を示している。層厚は $200 \mathrm{~m}$ 以上である。上部層は，， ジュールを含も塊状中粒砂岩で，ときにスランプ構造が 見られる。層厚は $30 \mathrm{~m}$ である。西山層は, 暗灰色〜带 緑灰色塊状泥岩（粘土岩）からなり, 風化すると細かく 砕けるのが特徴である。また，かなり連続のよい中粒砂 岩層や砂岩泥岩互層の部分をはさむ。層厚は $450 \mathrm{~m}$ であ る。灰爪層は, 青灰色塊状砂質シルト岩または各単層の 厚さが $5 \sim 10 \mathrm{~cm}$ の砂質シルト岩細〜中粒砂岩互層から なる。層厚は $280 \mathrm{~m}$ である。魚沼層は，黄褐色粗粒砂・

細粒〜中粒磷岩・泥岩の互層からな り，側方変化がはげしい。層厚は $240 \mathrm{~m}$ 以上である。今回の研究にと って，岩相変化がはげしいのは好ま しくないので, 魚沼層については調 查しなかった。

\section{3. 山中背斜の構造}

図-2 に执いて注目すべきことは， 同じ灰爪層の分布するところでも， 軸部の八重沢付近では大規模な地す ベりを起しているのに対し, 翼部で は嶺をつくっていて, 地すべりを起 していないことである。岩質はまっ たく同じシルト岩であるのに, 構造 的位置の違いによって, このように 地すべりの発達に差異があるのはな ぜで㐫らうか，そこで，まず野外に 颃いて, 構造地質学的な調查を行な った。

\section{（1）大構造}

因-4 は，層理面の極をシュミッ 卜網上半球に投影した $\pi$ ーダイヤグ ラムである。しゅう曲軸は, 北方の 塩沢付近で, $\mathrm{N} 30^{\circ} \mathrm{E}$ の方向へ $20^{\circ}$ プランジしているのに, 山中付近で はほぼ水平になっている。これは， 地質図に示されているように，山中 付近ではドーム状構造になっている からである。杤ヶ原付近は, 胴切り 断䅧でずれていたり，しゅう曲軸が 屈曲しているため, 地層の走向傾斜 

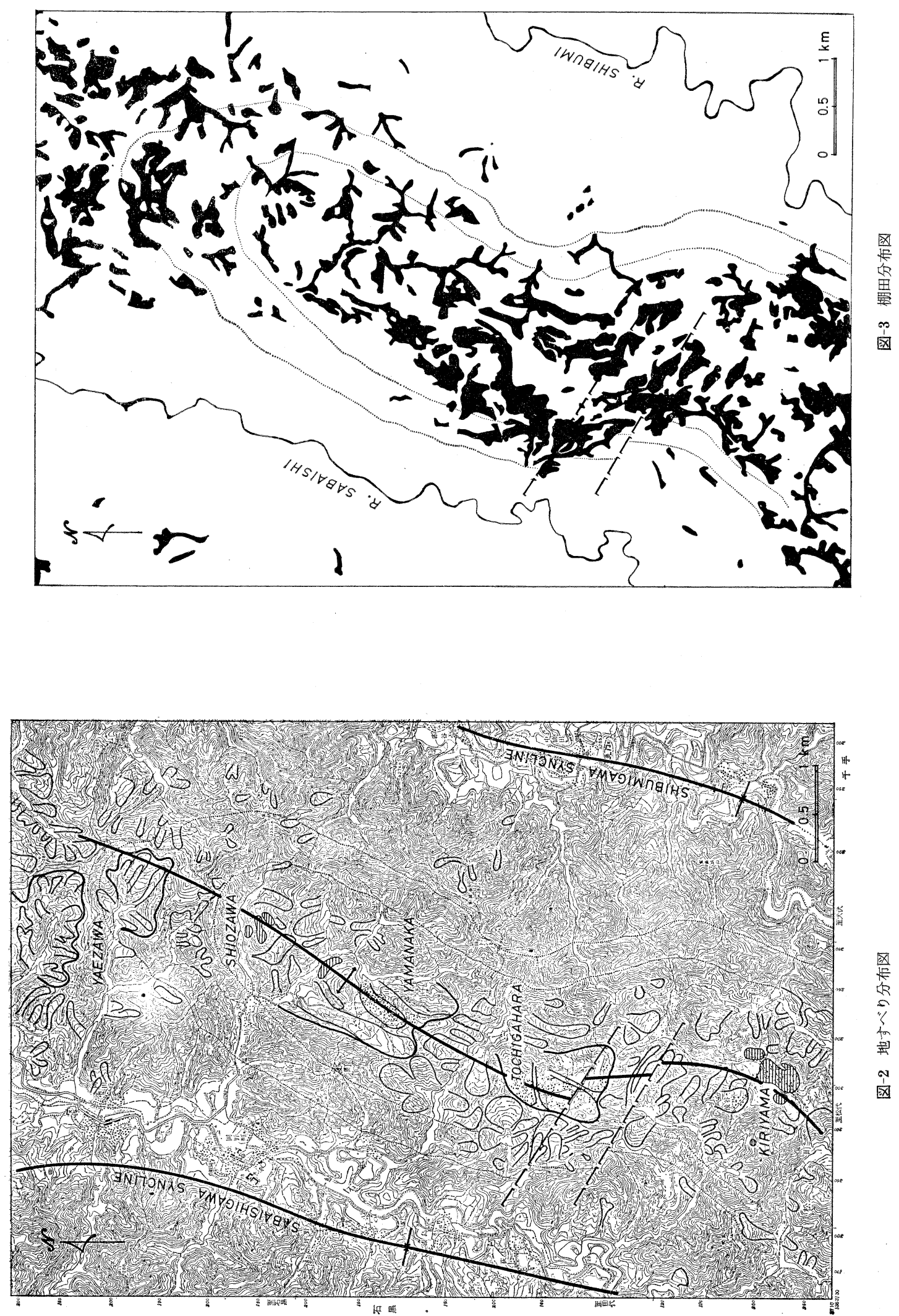

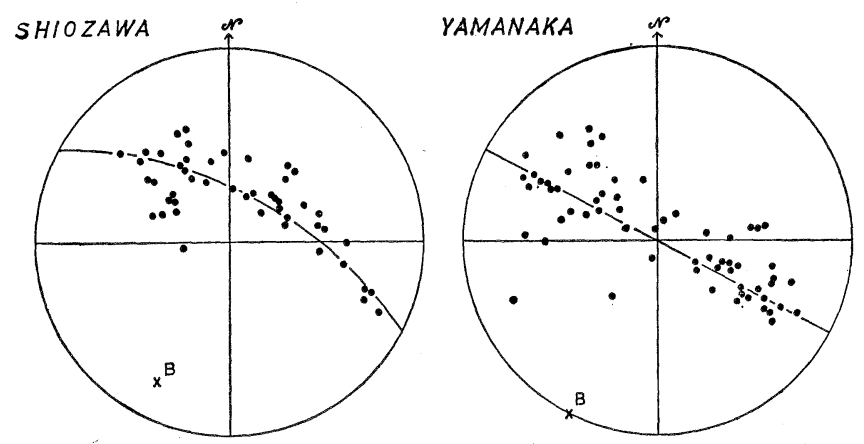

向にも水平方向にも曲りくねっていて, 決して直線的ではない。地質図から断面図 を描くと図-5のようになり，地層の厚さが 一定と仮定して描くバスク図法がほぼ適用 できる。つまり，形態的には同心しゅう曲 とみなしてよいるのと思われる。

\section{(2) 楼㼭}

断裂系とはいっても, 小断層の発達はあ まり良好ではないので，主として節理系を 中心に解析を行なった。図一は，各露頭で 測定した節理系の方位をサブ・エリアごと
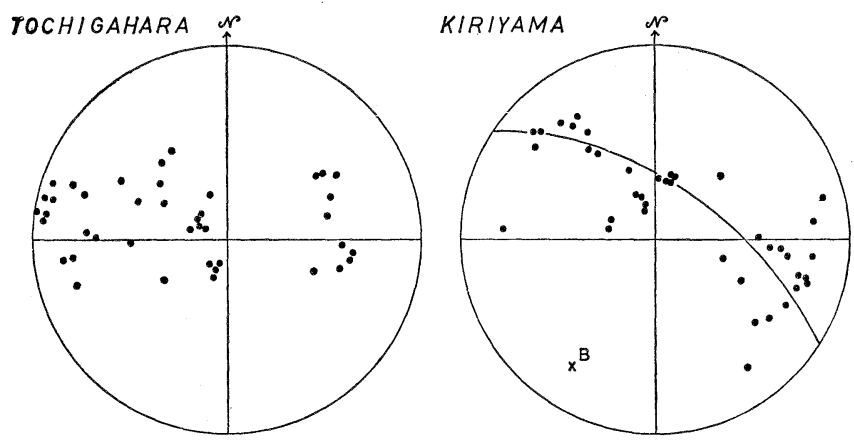

图-4 層理面の $\pi$-ダイヤグラム（シュミット網上半球投影） B：しゅう曲軸

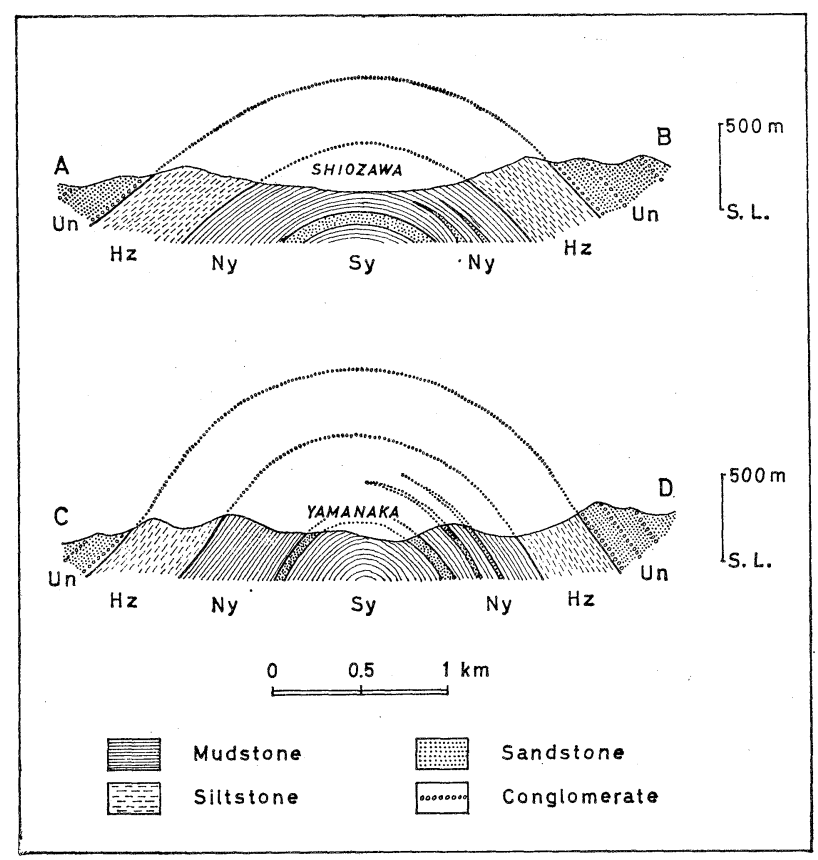

図-5 地質断面図

$\mathrm{Sy}$ : 椎谷層, $\mathrm{Ny}$ ：西山層, $\mathrm{Hz}$ ：灰爪層, $\mathrm{Un}$ ：魚沼層 にまとめて，その代表的方位をウルフ網上 半球に投影したものである。ここで，一番 よく発達しているのが胴店切り性節理で, とくに背斜軸部において発達が著しい。こ れは，しゅう曲軸にほぼ直交し，かつ，層 理面に対してもほぼ垂直である。一般に連 続性に乏しく，ある単層内に限られて発達 することも多い。節理面の性質は開口型4) であまり平滑ではなく，ときに $1 \mathrm{~cm}$ 程度 の褐鉄がしみこんでいることもある。また， 山中付近のドーム状構造の部分では, この 節理系に平行な厚さ $3 \mathrm{~cm}$ ほどの砂岩岩脈 がみられた。このよらな野外の事実から, この節理系は, しゅら曲の発達に伴ってで きた伸長性割れ目と考学られる。その他の 節理系は，胴切り性のものにくらべたら， やや発達の程度が悪く, 方向も場所によっ て異なることが多い。面の性質は開離接触 型4)で,一般に平滑直線的で連続性もよい。 また，付近の小断壃と平行なことが多い。 このよらなことから，これらはせん断性割 れ目と考えられる。

な和，山中・栃ケ原付近に执いて, 縦走 性の砂岩岩脈が見られた。また，図示され たものにくらべたらやや発達が悪いが，そ の他さまざまの方向をもった節理も見い出 される。これらは，しゅら曲軸のとら曲き 屈曲に伴ってできた別系統の割れ目であろ 亏。

\section{4. 岩石の力学的試験}

次に, 構造的位置の違いによって, 岩石 の力学的性質それ自体がどのように相違し ているのか，高圧岩石三軸圧縮試験機を用 が乱れていて,はっきりとした大円を描かない。さらに南 方の桐山付近では，もと通り $\mathrm{N} 35^{\circ} \mathrm{E}$ の方向へ $20^{\circ} \sim 25^{\circ}$ プランジしている。このように, しゅら曲軸は, 上下方

いて，岩石の変形破壊実絤を行なった。

(1) 試料

試料の採集には，チェーン・ソーのエンジンに改良を加 


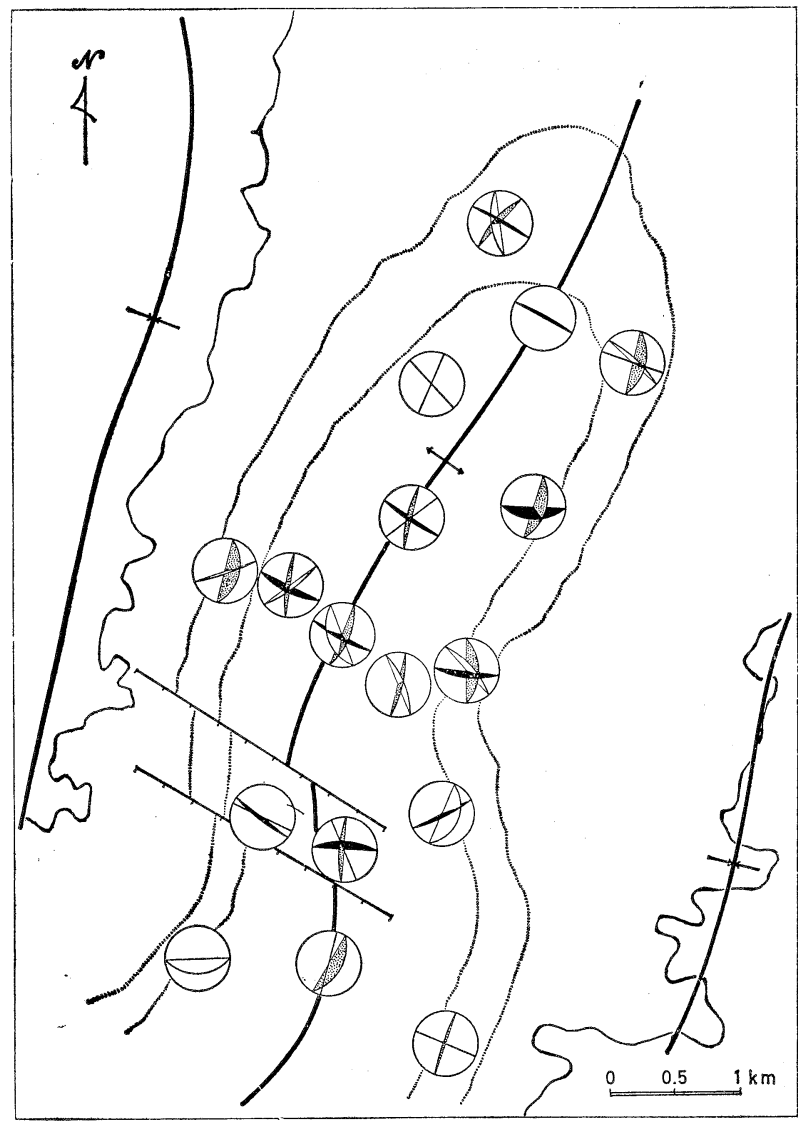

図-6 節理系統図（ウルフ網上半球投影）

黒 : 胴切り性節理, 点 : 縱走性節理, 白 : 斜交性節理

えて，ダイヤモンド・ビットをつけた，コアリング・ ドリル5゙を使用した。これを使うと, 直径 $40 \mathrm{~mm}$, 長さ $15 \mathrm{~cm}$ くらいのコアを取ることが可能である。風化の影 響をさけるため，なるべく沢底の常に流水で洗われてい るよらな新鮮な露頭を選び，試料を採集した。また，異 方性の影響を除くため, 試料はすべて層理面に垂直に取 った。試料は，なるべく同一層準で，しゅら曲のいろい ろな位置にあるものを採集するよう心がけた。層準がは っきりと招さえやすく，しかも岩質がどこでも均質であ ることが望ましいわけであるが，この条件を満している のは，灰爪層上部と下部の砂質シルト岩和よび西山層上 部の泥岩（粘土岩）である。図-7 は試料採取地点を示し たものである。な和, 同一地点で数個の試料を採取した。

こうして採集してきた岩石を，室温で 2 週間〜 1 力月 風乾し, 旋盤で直径 $19.5 \mathrm{~mm}$, 長さ $39 \mathrm{~mm}$ の円柱形に 成形した。その際，試料が変形するおそれがあるため， 冷却水は用いなかった。三軸試験では，両端面の平行度 が一番問題になるので，精度は $1 / 500$ 以内に括さめた。 以後は室温 $20^{\circ} \mathrm{C}$, 湿度 $60 \%$ の恒温恒湿の部屋に保存 して実験を行なった。

(2) 装置
実験には，新潟大学理学部の島津製作所製高圧岩 石三軸圧縮試験機を用いた。この機械は，本体（荷 重発生部分と高圧容器), 封圧制御部および記録計 の三者からなりたっている。荷重は, ねじこみポン プを用いて，油をメイン・シリンダーに送りこむこ とにより求められる。最大荷重は50tonである。ひ ずみ速度は，このねじこみポンプのギヤ比を変える ことによって, 長さ $39 \mathrm{~mm}$ の供試体に対して, $1 \times 10^{-n} / \sec (n=3,4,5,6,7)$ の 5 段階に切り換える ことができる。封圧は油圧を用い，最大 $3000 \mathrm{~kg} /$ $\mathrm{cm}^{2}$ まで加えることができる。塞験中の封圧の変動 に対しては, 容積マイクロメーター式圧力調整器を 用いて微調整することが可能である。荷重はロード ・セル，変位は差動トランスを用いて，X-Y レコ 一ダーに自記させるようになっている。なお，この 装置は，電気炉によって $200^{\circ} \mathrm{C}$ まで加熱すること ができる。

\section{（3）実験条件と手順}

すべての実験は,ひずみ速度 $1 \times 10^{-4} / \mathrm{sec}$, 室温 $\left(20^{\circ}\right.$ $\left.\mathrm{C} \pm 3^{\circ} \mathrm{C}\right)$ で行なった。同一地点からとった試料に ついて, 封圧は, $1 \mathrm{~kg} / \mathrm{cm}^{-2}$ (一軸状態), $50 \mathrm{~kg} / \mathrm{cm}^{-2}$, $100 \mathrm{~kg} / \mathrm{cm}^{-2}, \quad 250 \mathrm{~kg} / \mathrm{cm}^{-2}, 500 \mathrm{~kg} / \mathrm{cm}^{-2}, 1000 \mathrm{~kg} /$ $\mathrm{cm}^{-2}$ を与えた。試料の個数の少ないものは, $1 \mathrm{~kg} /$ $\mathrm{cm}^{-2}, 500 \mathrm{~kg} / \mathrm{cm}^{-2}, 1000 \mathrm{~kg} / \mathrm{cm}^{-2}$ の順に優先した。 試料を油からシールするために，銅チューブを焼きな まし，さらに硝酸で溶かして薄くした銅ジャケットを使

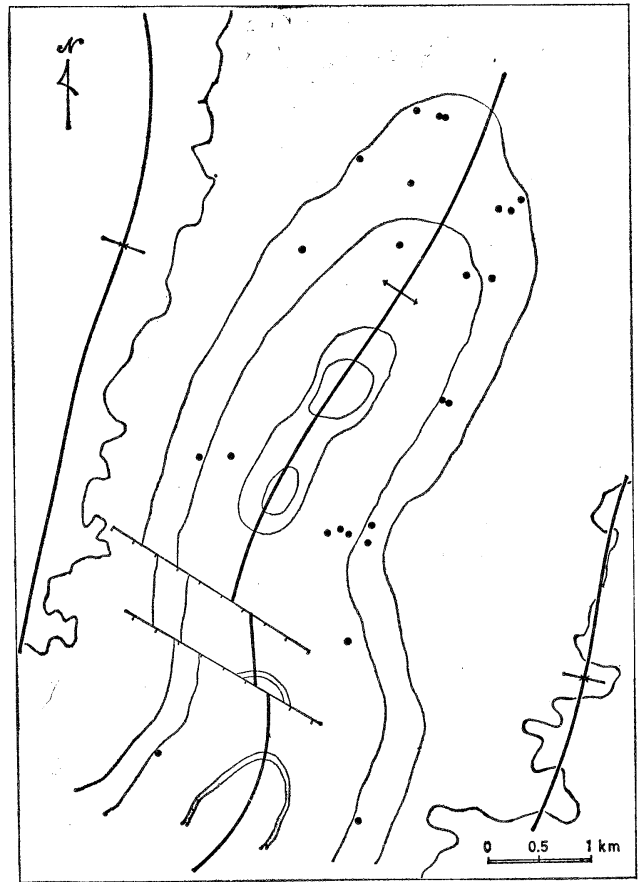

図-7 試料採取地点 
用した。一軸圧縮試験のときは, 銅ジャケットがある と, 結果的に封圧効果を生ずるおそれがあるため，2 枚 の薄い銅板で試料をはさむようにした。

このようなシールを行なったら光で, 試料をまず静水 王状態に和き，それから荷重を加兄はじめる。試料が破 壞したものは，そこで実駼を中止し，破壊を起さないる のは，ひずみが 18〜20\% に達したところで, 荷重を加 觉るのを中止した。

次に，記録計に表われるのは荷重一変位曲線であるか ら, 実験中試料の体積変化はないと仮定して, 応力ーひ ずみ曲線を得た。

\section{(4) 実験結果}

西山層の泥岩（粘土岩）と兏爪層のシルト岩とをくら ベると, 一般に, 前者のほうが一軸最大圧縮強度が大き く,そのときのひずみ量も大きい。また, 変形様式をみる と, 灰爪層のシルト岩は, ごく低封圧 $\left(100 \sim 200 \mathrm{~kg} / \mathrm{cm}^{-2}\right)$ でも,Hoshino et. al. (1972) の分類による延性型から粘 延性型を示す ${ }^{-6)}$ 。そのとき, 試料はタル型にふくらむか, もとの円柱状の形態を残したまま全体として大きさが縮 小する。一方, 西山層の泥岩は, 低封圧ではぜい性的な 破壊を起し，封圧が高くなると中間型を終て延性型に移 行する。な招, 変形様式・破壊形態などの詳細は, 本論 文の趣旨からはずれるので，別に報告する予定である。

\section{5. 背斜内の構造的位置と岩石の力学的性質}

前述のように，背斜の軸部と翼部とで，地すべりの発 達に顕著な差がある。そこで, 岩石の力学的性質と構造 的位置との関係を検討してみることにする。構造的位置 は, ひとつの目安として, 背斜軸からの水平距離を採用 した。

\section{（1）密度と一軸強度}

図-8左図は，実験前の試料の容密度（温度 $20^{\circ} \mathrm{C}$, 湿 .度 $60 \%$ ), 右図は一軸最大玨 縮強度をそれぞれ縦軸飞と り，横軸に背斜軸からの水平 距離をとったものである。こ の図から, 密度・強度ともに, 下位の地層から上位の地層一 いくにしたがって，隇少する ことがわかる。これは，主と して, 上に堆積した地層の荷 重によるものと思われる(6),

しゅら曲との関係について みると, 西山層では軸部に近 づくにしたがって, 密度も強 度もともに減少する傾向がう かが党るが，灰爪層では明膫 でない。しかし, 強度と密度
との関係をグラフに描くと（図-9)，西山層・灰爪層の それぞれについてタ,机柋，軸部のものは左下部汇，翼部 のものは右上部にグループ分行できる。やはり，朝部で は密度・強度ともに小さく、翼部ではとも大さくなる 傾向が認められる。

\section{(2) ダクティリティとヤング率}

Handin \& Hager (1957) は，応力-ひずみ曲線沉 いて，破壊点のひずみ\%をもってダクティリティ（延展 度）と定義した ${ }^{8)}$ 。しかし，一般には破壊点を明確に求 めることは困難なので，Donath \& Faill（1963）は，最 大強度点に抢けるひずみ\%と再定義した ${ }^{9)}$ ここでは, こ の定義にしたがうことにする。一般に, 同じ強度の場合, ダクティリティが小さいと, 極ぜい性型の変形を示し, 大きくなるにしたがって，より延性的に変形する。一種 の流動しやすさを示す指標とい光よう。図-10 左図の綎 軸には, 一軸試験に和けるダクティリティがとってあ る。明らかに, 西山層・灰爪層下部・灰爪層上部の三者 とも，それぞれ右さがりの傾向が認められる。つまり， 軸部へ近づくほど, ダクティリティは大きくなる。すな わち, 同一層準の岩石では, 軸部ほど流動しやすいとい らことを意味している。もちろん, 強度が異なるので, 西山層のほうがダクティリティが大きいからといって, 灰爪層にくらべてょり流動しやすいというわけではな い。

次に，一軸圧縮試験で，極ぜい性型の変形をするもの について，割線ヤング率を求めた。これは，応力ーひず み曲線の原点とひずみ $1 \%$ の点とを結んだ直線の勾配と して計算した。図-10右図の縦軸には,このヤング率がと ってあるが，やはり，軸部へ近づくほど小さくなる傾向 が認められる。つまり,軸部のほうがよりひずみやすい。

\section{(3) 三軸応力下におけるひずみ}

封压を加えると，変形はより延性的になるので，最大 ULTIMATE STRENGTH

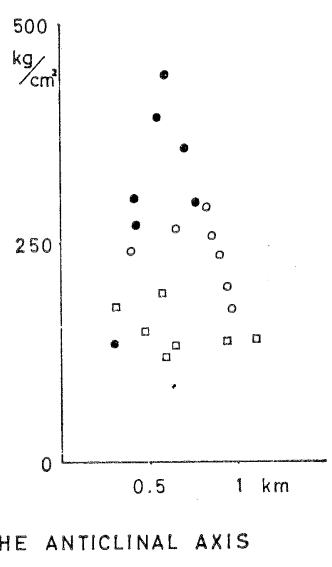

- UPPER haIZUME F.

- lower haizume f.

- nishiyama F.

図-8 密度と一--軸最大強度 


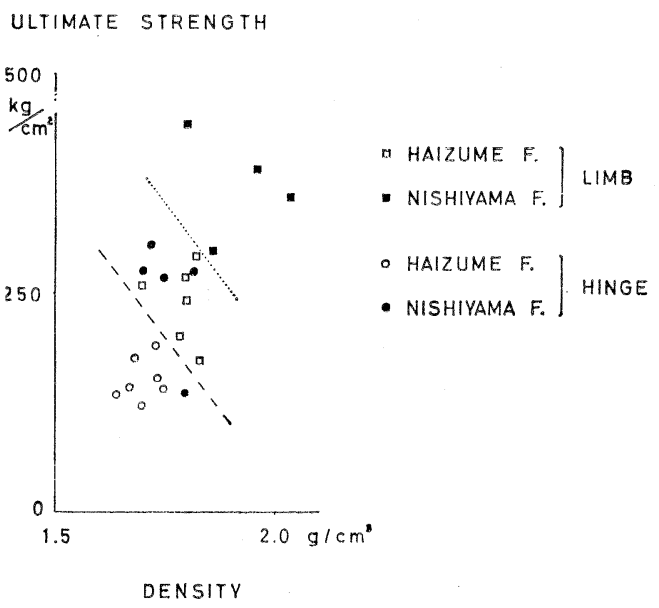

図-9 最大強度対密度図

DUCTILITY

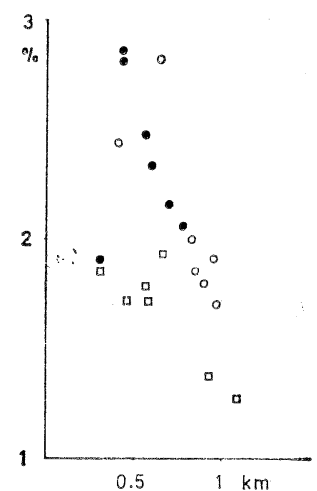

DISTANCE FROM THE ANTICLINAL AXIS

図-10 ダクティリティとヤング率
YOUNG'S MODULUS

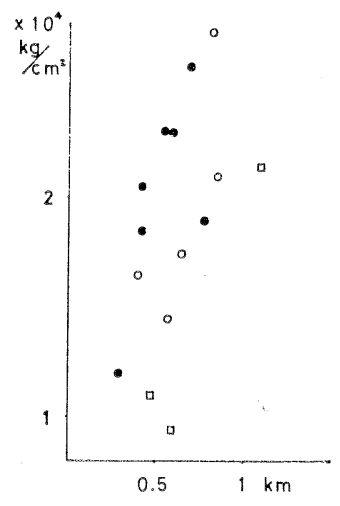

AXIAL SHORTENING at $1,000 \mathrm{~kg} / \mathrm{cm}^{2}$

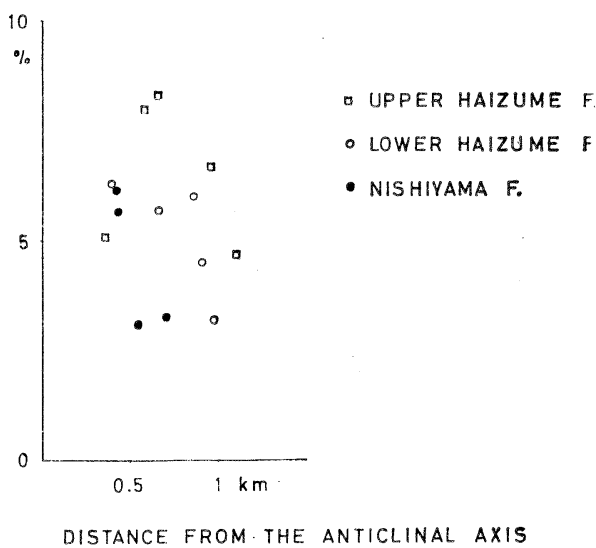

図-11 静水生 $\left(1000 \mathrm{~kg} / \mathrm{cm}^{2}\right)$ 下での縦ひずみ
- UPPER HAIZUME F.

- lower haIzUMe F.

- nishirama F.

\section{6. 考 察}

岩石の変形破壞 実験の結 果, 背斜内の構造的位置によ って, 同層準同岩質の岩石で も, その力学的性質に違いの あることがわかった。それ は, いずれも, 軸部では翼部 にくらべて，よりひずみやす いことを示している。しか し，ここで用いた試料は，寸 でた天然のしゆら曲によって 変形した岩石である。このこ とは何を意味するのであろう か。网-8でみられるよらに, 同一層準の岩石の場合，その 密度にはそんなに大きな差はない。となると，岩石の内 部構造に違いがあるということになる。つまり，翼部に くらべて軸部では，しゅら曲時に相対的に大きな流動が あり，構成鉱物が再配列を起すなどして，微小なすべり 面のよらなものができたものと考觉られる。すなわら， ここのしゅう曲は Donath \& Parker (1964) の分類によ る flexural flow fold である ${ }^{10)}$ 。な拉，地質断面図に括 いて，層厚がそんなに変化していないことは，流動の量 があまり大きくないことを示している。

さて, このような構造的位置による力学的性質の差違 をもたらした原因は何であろらか。一般的に, 風化・埋 没深度の差・膠結物質の差・造構応力の差などが考兄ら れる。風化については, 露頭から試料を採取した以上, 十分考えられるが，沢底の新鮮な岩石を用いたし，なに よりも，風化によるものとすれば，構造的位置によらず もっとばらつき, 系統的な差にはならないであろう。埋 
没深度の差については，たしかに西山層と灰爪層の差の

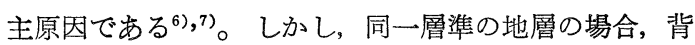

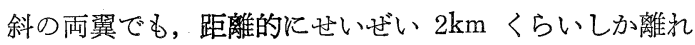
ていないし，地質断面図からも有意の差を認め難い。岩 石の膠結物質については，佐藤（1972）によれば，同層 準の地層で，構造的位置の違いによって，糖土鉱物の組

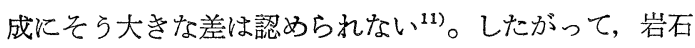
の力学的性質の差は, 構造的位置による造構応力の差に よるものと考党てよい。

このような岩石の力学的試験の結果と, 前述の断裂系 の研究結果を総合すると, 次のようにい光る。しゅう曲 の軸部と翼部では受けた造構応力が異なり, 軸部は, 流 動が相対的に大きく, 岩石の内部構造がみだされて“弱 く”なっている。そのため, 地すべに対する抵抗力も 低下する。その上，開口型の伸長節理が発達するような 引っ張り応力下に扔かれたため, さらに強度が低下し， その割れ目に沿って地下水が浸透するなどして, 風化が 促進される。その結果, しゅら曲軸部に地すべりが多発 するものと思われる。なお，山中や栃原のように，乙 ゅう曲軸がとう曲したり屈曲したりしている場合には, それに伴ら別系統の割れ目が重なって，より一層地すべ りを起しやすくしているものと思われる。るちろん，新 潟のような活しゅう曲地带では, 背斜は隆起して山陵部 になっているので,この地形的な影響も大きい。

\section{7. おわりに}

以上述べてきたように，地すべりと地質構造扔よび岩 石の力学的性質とは，非常に密接な関係がある。つま り，「獲得因子」のいかんによって，地すべりに対して も大きな影響がある。したがって，地すべりを研究する 際, 地形・地下水・気象などの調查や, 地すべり地に招 ける表層部の地質調查ばかりではなく, 基盤の構造地質 学的構造物理学的基礎調查がぜひとも必要である。ま た，岩石の力学的性質に関する基碟研究も重要である。

この研究をまとめるにあたり, 新潟大学植村 武教授 には大変有益なご助言をたまわった。るた，試料の成形 には，東北大学理学部の設備を使わせていただいた。そ の際, 同大学北村 信教授・大梘憲四郎氏にいろいろ招 世話になった。厚く謝意を表する次第である。

な拈, この研究には, 自然災害待別研究の科学研究費 を使用した。

\section{引用文献}

1）植村 武 (1974): 地すべり分類の基準について, 地すべりの分類に関するシンポジウム講演論文集, pp. 1-7.

2）津田禾粒・岩永 伸・西田彰一 (1967)：第 3 紀 層地すべりと岩質括よび地質構造との関係一新潟県 下の第三紀層地すべりについて一, 災害地質討論会 論文集, pp. 58-70.

3）渡辺久吉（1938）：大日本帝国油田図第 36 区（岡 野町油田), 地質調查所。

4）衣笠善博 - 垣見俊弘 - 平山次郎 (1969): 房 総半 島東海岸の小断層, 地質調査所月報, Vol. 20, No.

1, pp. 13-38.

5) H. Ueno \& M. Nedachi (1970) : Apparatus for determining magnetic susceptibility of rocks and ores in a weak magnetic field, Sci. Rept. Tohoku Univ., Ser. III, Vol. 11, No. 1, pp.1-13.

6) K. Hoshino, H. Koide, K. Inami, S. Iwamura \& S. Mitsui (1972): Mechanical properties of Japanese Tertiary sedimentary rocks under high confining pressures, Rept., Geol. Surv. Jap., No. 244, pp. 1-200.

7）松沢 明 $(1961 \cdot 1962)$ : 堆樍岩の密度之地質構 造, 物理探鉱。 Vol. 14, No. 4, pp. 36-45., Vol. 15, No. 1, pp. 1-13.

8) J. Handin \& R. V. Hager, Jr.' (1957) : Experimental deformation of sedimentary rocks under confining pressure : Tests at room temperature, Am. Assoc. Petrol. Geologists Bull., Vol. 41, No. 1, pp. 1-50.

9) F.A. Donath \& R.T. Faill (1963) : Ductile faulting in experimentally deformed rocks (Abstract), Am. Geophys. Union Trans., Vol. 44, pp. 102-103.

10) F.A. Donath \& R.B. Parker (1964) : Folds and Folding, Geol. Soc. Am. Bull., Vol. 75, No. 2, pp. $45-62$.

11）佐藤憲司（1972）：背斜軸部における地すべり地 域の土質化学的性質, 新潟大·理 - 卒論 (M.S.)。 